\title{
A CONTRACTARIAN CRITIQUE OF THE THEORY OF AUTO-LIMITATION: THE FUNDAMENTAL LAW OF INTERNATIONAL RELATIONS
}

\author{
ERIC S. WILENSKY ${ }^{\dagger}$ \\ INTRODUCTION
}

\section{A. The Problem}

The year is 2085. Five years ago the Supreme Court overruled Roe v. Wade. ${ }^{1}$ The Supreme Court has just upheld against constitutional challenge a federal law that prohibits abortion throughout the country. The Court's reasoning is that life begins at conception and is present throughout pregnancy; and therefore, the federal government has a compelling interest in protecting that life beginning at conception. $^{2}$ Subsequently, the government of Vermont has issued a statement that it will not abide by the Supreme Court's decision and will use its state national guard to keep abortion clinics open. ${ }^{3}$ Its argu-

${ }^{\dagger}$ B.A. 2000, Hofstra University; J.D. Candidate 2003, University of Pennsylvania. I would like to thank my family, Alan, Georgann, and Carrie Wilensky, for their support. Special thanks to Professor Claire Finkelstein, who read through numerous drafts of this Comment and without whose help this Comment would not have been possible. Thanks also to Professor Freidrich Kübler, who provided constructive cricitsm on my presentation of the European Union's structure and institutions, Professor William Ewald, whose insights on both Hobbesian and international law theory improved my understanding of the subjects, and to Toni Amato, Courtney Breen, Lisa Campbell, Christine DiGuglielmo, John Eustice, and Lindsay Goldman of the University of Pennsylvania Law Review, whose help was immeasurable during the editing process. Finally, thanks to Mr. G. LeMay, who three years ago sparked an academic interest that has not subsided. All errors contained herein are my own.

${ }^{1} 410$ U.S. 113 (1973). In that case, the Supreme Court constructed a trimester approach to a state's right to regulate abortion. Id. at 162-64. During the first trimester, no state interest could overrule the right to have an abortion. Id. During the second trimester, only the state's interest in the health of the mother would justify restrictions on the right to abortion, so long as those restrictions were rationally related to her health. Id. Finally, during the third trimester, the state may have an interest in the fetus itself, and thus may outlaw or restrict abortion. Id.

${ }^{2}$ This was exactly Texas's argument in Roe $v$. Wade. Id. at 159.

'Vermont's actions would be in violation of the Supremacy Clause of the United States Constitution, which holds that, "the Laws of the United States . . . shall be the supreme Law of the Land." U.S. CONST. art. VI. 
ment is that the Constitution created a dualist system of government, ${ }^{4}$ in which domestic (Vermont) and international (United States) laws operate with different purposes and constituencies. Essentially, Vermont argues that since the signing of the Constitution, each law of the United States had to be accepted separately into Vermont law (or, alternatively, not rejected by the Vermont government) before it acquired binding force within the state. While previously it never exercised its right to negate federal law, Vermont argues that it always has retained the right to invalidate a United States law.

Vermont's argument, indeed entirely hypothetical, seems quite preposterous. ${ }^{5}$ An American state never would disregard a Supreme Court opinion based on this argument. This state of certainty, however, does not exist within the European Union. Today, "the courts of the Member States ${ }^{6}$ have understandably claimed a voice in determining the force and effect of Community law in their own domestic legal orders." ${ }^{7}$ In Brunner v. European Union Treaty, the German Federal Constitutional Court went so far as to state that Germany retains its sovereign right to rescind its membership in the Union at any time. ${ }^{8}$ The basic argument that is taking place within the European Union, both in the realm of the courts and the realm of politics, is over the nature and scope of international law. ${ }^{9}$

Whether international law is really law is a question that legal

${ }^{4}$ For a description of the dualist approach to international law and the contrasting monist approach, see GEORGE A. BERMANN ET AL., CASES \& MATERIALS ON EUROPEAN COMMUNITY LAW 204-06 (1993) [hereinafter BERMANN ET AL., EUROPEAN COMMUNITY LAW].

${ }^{5}$ The Constitution of the United States would not provide a good base upon which to build for the purposes of this Comment. The Preamble to the Constitution reads, "We the People of the United States." U.S. CONST. pmbl. (emphasis added). From these words, one may argue that the people of the United States were party to the treaty as opposed to the various states. Here, I deal with agreements where sovereign states are themselves party to an international treaty. I use this example merely to show the relevance of the problem.

${ }^{6}$ The various nations that are members of the European Union are commonly referred to as "Member States."

7 BERMANN ET AL., EUROPEAN COMMUNITY LAW, supra note 4, at 166.

${ }^{8}$ [1994] 1 C.M.L.R. 57, 61 (BVerfGE 1993) (F.R.G.) ("Germany is one of the 'Masters of the Treaties' with the intention of long-term membership; but it could also ultimately revoke its adherence by a contrary act.").

${ }^{9}$ See, e.g., George A. Bermann et al., Cases and Materials on European COMMUNITY LAW 125 (Supp. 1998) [hereinafter BERMANN ET AL., SUPPLEMENT] (noting the assumptions that the German constitutional court has made about the nature of the European Union); The Latest Battle for the Continent's New Shape, ECONOMIST, Dec. 8,2001 , at 47 (discussing the current political debate about the legal nature of the European Union). 
theorists long have dealt with. ${ }^{10}$ Professor H.L.A. Hart recharacterized this fundamental question by separating it into two separate inquiries: (1) How can international law be binding?" and (2) Are states fundamentally capable of being the subjects of legal obligation? ${ }^{12}$ I will deal strictly with the second of these two issues, for it forces me to confront an inherent conflict in the concept of international law. If states are sovereign entities, then they must have complete and total power. But as soon as one contemplates an international legal structure, one must contemplate a sovereign state of limited powers. ${ }^{19}$

I will show that this conflict-which on its face seems to prevent the formation of an international legal structure ${ }^{14}$ to coexist with sovereign states-is merely illusory. In doing so, I will provide a framework in which to analyze specific treaties to determine whether or not they have created an international legal structure that avoids this conflict. I will do this by showing that at times sovereign states are not only permitted, but also are naturally obligated to cede a portion of their sovereignty, thus becoming subjects of legal obligation and limiting their autonomy.

In order to accomplish this, I expand on the contractarian theory of Thomas Hobbes. ${ }^{15}$ I use a contractarian theory specifically because

${ }^{10}$ See, e.g., H.L.A. HART, THE CONCEPT OF LAW 213-37 (2d ed. 1994) (questioning whether international law could be deemed valid law); Steven R. Ratner \& Anne-Marie Slaughter, Appraising the Methods of International Law: A Prospectus for Readers, 93 AM. J. INT'L L. 291 (1999) (tracing the history of methods of studying international law).

"See HART, supra note 10, at 216 ("The first [form of doubt] has its roots deep in the conception of law as fundamentally a matter of orders backed by threats and contrasts the character of the rules of international law with those of municipal law."). This first question Hart posits may be asked of municipal (or non-international) law as well. See id. at 1-78 (questioning the validity of models of municipal law that are based on the theory that law is merely a sovereign's coercive orders).

${ }^{12}$ See id. at 216 ("The second form of doubt [is] that states are fundamentally incapable of being the subjects of legal obligation, and contrasts the character of the $s u b$ jects of international law with those of municipal law.").

${ }_{13}$ This seemingly inherent conflict is accepted by some theories of international law. See, e.g., Louis HeNkin, How Nations BeHAVE 17 (2d ed. 1979) ("Except as limited by international law or treaty, a nation is master in its own territory."); Claudio Grossman \& Daniel D. Bradlow, Are We Being Propelled Towards a People-Centered Transnational Legal Order?, 9 AM. U. J. INT'L L. \& POL'Y 1, 1-9 (1993) ("[I]nternational law has traditionally been concerned with the relations between co-equal sovereign states.").

${ }^{14}$ See infra notes 47-49 and accompanying text (explaining the definition of international legal structure).

${ }^{15}$ My arguments are thus limited to commonwealths formed in contractarian systems, as the formation of the European Union can be conceptualized. For a brief introduction to the work of Hobbes, see 1 JOHN Plamenatz, MaN AND Society: A CRITICAL EXAMINATION OF SOME IMPORTANT SOCIAL AND POLITICAL THEORIES FROM 
I find that theory the most compelling as to the formation of government. I use Hobbes's work because he too identified this fundamental conflict between autonomous creatures and the formation of a government. In his writings, however, he dealt with the autonomous individual and the formation of a sovereign state; he did not deal with sovereign states and the formation of an international legal structure.

As briefly shown above, the European Union ${ }^{16}$ currently provides the best example of the importance of this issue. ${ }^{17}$ While the European Union can point to the European Coal and Steel Community as its origin, ${ }^{18}$ the institution's structure and scope has tended toward a more centralized international legal structure. ${ }^{19}$ The European Court

MACHIAVELLI TO MARX 116-54 (1963).

${ }^{16}$ The European Union is a complex legal structure made up by three "pillars." BERMANN ET Al., SUPPLEMENT, supra note 9, at 3. These pillars are the European Communities, the system of foreign relations, and the system of domestic security. Id. The first pillar, the European Communities, is made up of the European Community, the European Coal and Steel Community, and the European Atomic Energy Community ("Euratom"). Id.; BERMANN ET AL., EUROPEAN COMMUNITY LAW, supra note 4, at 58. For the sake of simplicity, I will refer to any part of the structure simply as the European Union.

${ }^{17}$ While I will continually use the European Union (or a smaller hypothetical variant on it) throughout the Comment, my primary goal is to provide a framework for analyzing the nature of any international treaty. My goal is not simply to solve one issue within the European Union. For example, while it seems quite clear the United States has the right to withdraw from the ABM treaty, see Treaty on the Limitation of Anti-Ballistic Missile Systems, May 26, 1972, U.S.-U.S.S.R., art. XV, 23 U.S.T. 3435, 3446 ("Each party shall, in exercising its national sovereignty, have the right to withdraw from this Treaty if it decides that extraordinary events related to the subject matter of this Treaty have jeopardized its supreme interests."), one could use this framework to analyze whether the United States has that right with respect to any of its other treaties.

18 Treaty Establishing THE European CoAl and STEEl Community, Apr. 18 1951, 261 U.N.T.S. 140; see also BERMANN ET AL., EUROPEAN COMMUNITY LAW, supra note 4, at 1-21 (tracing the history of the European Union).

${ }^{19}$ See Treaty ESTABlishing a Single Council AND a Single Commission of THE EUROPEAN COMMUNitiES (MERGER TREATY), July 13, 1967, 1967 O.J. (L 152) SPEC. Ed. 1 (establishing a Single Council and single Commission of the European Communities, as opposed to separate institutions for the European Economic Community, Euratom, and the European Coal and Steel Community); SINGLE EuROPEAN ACT, opened for signature Feb. 17, 1986, O.J. (L 169) 1 (1987) (authorizing European Union legislation in environmental protection, occupational safety and health, research and technological development, and regional development, as well as giving the European Parliament a greater role in the legislative process); TREATY ON EUROPEAN UNION, Feb. 7, 1992, O.J. (C 191) 1 (1992) [hereinafter TEU TREATY] (forming the European Union as it is currently constituted); TREATY OF AMSTERDAM AMENDING THE TREATY ON EUROPEAN Union, the Treaties Establishing the EUROPEAN COMMUNities and Certain RELATED ACTS, Oct. 2 1997, O.J. (C 340) 1 (1997) [hereinafter TREATY OF AMSTERDAM] (amending the Treaty on European Union and attempting to harmonize foreign policy and allow freer movement of individuals). 
of Justice, the highest court within the European Union, has attempted to capitalize on the treaty framework ${ }^{20}$ in order to assert its supremacy over Member State courts. In a decision that Professor Friedrich Kübler likens to the European version of Marbury $v$. Madison, $^{21}$ the European Court of Justice defined the European Community as a "new legal order of international law for the benefit of which the states have limited their sovereign rights." ${ }^{22}$ In response to this decision and, more importantly, to the growing apprehension of the loss of autonomy that Member State courts are facing, many Member State court decisions have reserved the right of their respective states to opt out of the decisions of the European Court of Justice. For example, in Internationale Handelsgesellschaft mbH v. Einfuhr- und Vorratsstelle für Getreide und Futtermittel, ${ }^{23}$ the German Federal Constitutional Court stated that in the case of conflict between European Union law and German fundamental rights, German fundamental rights would prevail. ${ }^{24}$ Italian courts also have reserved their right to invalidate European Union law if it conflicts with "fundamental principles of [the Italian] constitutional order." As mentioned above,

${ }^{20}$ The European Economic Community, which is the major pillar of the three pillars establishing the European Union, is based on a series of treaties signed by each of the countries in the community. See supra note 16 (describing the distillation of the complex European legal structure into three pillars). See generally BERMANN ET AL., EUROPEAN COMMUNITY LAW, supra note 4, at 22-29 (describing the European Union's treaty framework). These treaties, taken as a whole, constitute what is known as the "treaty framework."

${ }^{21}$ Friedrich Kübler, Lecture to His Fall 2001 European Union Law Class at the University of Pennsylvania Law School (Oct. 18, 2001) (notes on file with author). In Marbury v. Madison, 5 U.S. (1 Cranch) 137 (1803), the case to which Professor Kübler refers, the Court held that it had the power to review acts of Congress and declare them void if found in violation of the Constitution. Id. at 177-78. Analogizing that case to the European Union, the Court of Justice has asserted that it has the power to review acts of the Member States and declare them void if found in violation of the treaty framework or European Union law.

${ }_{22}$ Case 26/62, van Gend en Loos v. Nederlandse Administratie der Belastingen, 1963 E.C.R. 1, 12, [1963] 1 C.M.L.R. 105, 129 (1963).

${ }^{23}$ [1974] 2 C.M.L.R. 540 (BVerfGE 1974) (F.R.G.).

${ }^{24}$ The court stated:

[I]n the hypothetical case of a conflict between Community law and ... the guarantees of fundamental rights in the [German] Constitution, there arises the question of which system of law takes precedence, that is, ousts the other. In this conflict of norms, the guarantee of fundamental rights in the Constitution prevails as long as the competent organs of the Community have not removed the conflict of norms....

Id. at 551 .

${ }^{25}$ See Frontini v. Ministero delle Finanze, [1974] 2 C.M.L.R. 372, 389 (Corte cost. 1973) (Italy) (stating that if the EEC were given "an unacceptable power to violate the 
one German court decision even asserts that Germany may opt out of the European Union at any time. ${ }^{26}$ An Italian court has also attempted to say, in a decision subsequently overruled by the European Court of Justice, that Italy may invalidate European Union Law simply by passing subsequent legislation. ${ }^{27}$ Thus, to a Member State that finds itself in the hypothetical situation that the German court presents in Internationale Handelsgesellschaft, ${ }^{28}$ where European Union law conflicts with fundamental constitutional principles, an argument that sovereign states can never give away even a portion of their sovereignty is an extremely powerful one. This argument, which Professor Hart defines as the "auto-limitation" theory, ${ }^{29}$ is a logical conclusion if one were to accept the conflict described above ${ }^{30}$ as a truism. Under the auto-limitation theory, "a state's agreements or treaty engagements are treated as mere declarations of its proposed future conduct, and failure to perform is not considered to be a breach of any obligation."

Under the framework with which I propose to analyze international treaties, the auto-limitation theory fails because at times, treaty engagements in fact create binding obligations upon contracting states. Thus, the framework I suggest eliminates the possible conflict between Member State and European Union courts, and eliminates the viability of the reservationist language that various Member State courts have included in their decisions concerning controversial European Union Law.

Specifically, the framework I propose will thwart the argument that the Irish Supreme Court makes in Society for the Protection of Unborm Children (Ireland) Ltd. v. Grogan. ${ }^{32}$ In that case, student unions and their officers published student handbooks with the names and addresses of abortion clinics in the United Kingdom. ${ }^{33}$ They did so even though article 40.3 .3 of the Irish Constitution protects the right to life

\footnotetext{
fundamental principles of [the Italian] constitutional order . . . [the Italian constitutional court] would control the continuing compatability of the Treaty with the abovementioned fundamental principles").

${ }^{26}$ See supra note 8 and accompanying text (discussing the German Federal Constitutional Court's holding in Brunner v. European Union Treaty).

${ }^{27}$ Case 6/64, Costa v. ENEL, 1964 E.C.R. 585, [1964] l C.M.L.R. 425 (1964).

${ }^{28}$ The hypothetical case is spelled out supra note 24.

${ }^{29}$ HART, supra note 10 , at 224.

See supra note 13 and accompanying text (describing the potential conflict).

31 HART, supra note 10 , at 224.

32 [1990] 1 C.M.L.R. 689 (Ir. S.C. 1989)

ss. at 692 .
} 
of unborn children and prohibits abortions. ${ }^{34}$ The plaintiffs sought a permanent injunction prohibiting the publication of these handbooks, ${ }^{35}$ but the defendants argued that an injunction would violate the European Union's guarantee of free movement of services. ${ }^{36}$ The Irish High Court sent a preliminary reference, the European Union version of certification, ${ }^{37}$ to the European Court of Justice asking for resolution of the issue. ${ }^{38}$ The Irish Supreme Court, however, decided that the right to life was a constitutionally protected right in Ireland and the application for the injunction was meant to restrain an unconstitutional activity. ${ }^{39}$ As to whether this violated a European Union right, the court stated:

If and when a decision of the European Court of Justice rules that some aspect of European Community law affects the activities of the defendants ... the consequence of that decision on these constitutionally guaranteed rights and their protection by the Courts will then fall to be considered by these Courts.

This statement challenges the authority of the European Court of Justice. It asserts the ability of the Irish Supreme Court to review and rule on a matter already decided by the European Court of Justice. I will prove this statement incorrect.

\section{B. The Structure of the Argument}

Under the auto-limitation theory, which stems from the conflict between autonomous sovereigns and an international legal structure, it is never permissible for sovereigns to cede any portion of their

${ }^{34}$ IR. CONST. art. 40.3.3.

${ }^{35}$ See Unborn Children, [1990] 1 C.M.L.R. at 697 (noting the plaintiff's reliance on article 40.3.3 of the Irish Constitution).

${ }^{36}$ See id. at 697-98 (reporting the defendants' argument that the constitutional right was qualified by a right flowing from European Community Law).

${ }^{37}$ Authorized by article 234 (article 177 under the old numbering) of the Treaty, the preliminary reference mechanism at times allows, and at other times requires, that a Member State court send an issue to the European Court of Justice for a ruling on the Community Law aspect of a particular case. TREATY ESTABLISHING THE EUROPEAN COMmUNITY, Nov. 10, 1997, art. 234, O.J. (C 340) 2 (1997) [hereinafter EC TREATY].

${ }^{38}$ See Unborn Children, [1990] 1 C.M.L.R. at 695 (noting the lower court's opinion that the preliminary ruling was necessary under the Treaty Establishing the European Community). While the reference was pending in the European Court of Justice, the plaintiffs appealed the decision to obtain a preliminary reference to the highest court in Ireland, the Irish Supreme Court. BERMANN ET AL., EUROPEAN COMMUNITY LAW, supra note 4 , at $233-34$.

${ }^{39}$ Unborn Children, [1990] 1 C.M.L.R. at 698-99.

${ }^{40}$ Id. at 699 . 
authority. ${ }^{41}$ I will show that at times, sovereign states are obligated to cede portions of their authority. Accordingly, an auto-limitation theory is inherently contradictory to a theory of international relations. A sovereign cannot have both an obligation to take an action and an obligation not to take that action. ${ }^{42}$ If the auto-limitation theory is false and states are at times obligated to create an international sovereign, it follows that they would be obliged to obey this newly created sovereign.

The process of showing that sovereigns are at times obligated to cede portions of their authority involves three steps. In Part I, I build a foundational understanding of the Hobbesian text. ${ }^{49}$ In this Part, I will argue that Hobbes's theory allows for the initial covenant to limit the authority of the sovereign. ${ }^{44}$ Accordingly, it will be necessary to explore the theory of authorization, which is central to the institution of the sovereign. In order to show why a sovereign may be required to

${ }^{41}$ One may argue that a ceding of authority is perfectly acceptable under an autolimitation theory. On this argument, a ceding of authority would not be permanentit would simply be a prudential act that could be nullified. See E-mail from William Ewald, Professor of Law and Philosophy, University of Pennsylvania, to Eric Wilensky (Mar. 19, 2002, 21:39:26 EST) (on file with author) ("A classical Hobbesian ... would agree that a sovereign can enter into a treaty or a customary practice, and for prudential reasons keep its promises-but without thereby surrendering any of its ultimate sovereignty, and without creating a new, super-sovereign."). For purposes of this Comment, a "ceding of authority" implies permanence-it is synonymous with a ceding of sovereignty. As such, it is incompatible with an auto-limitation theory.

${ }^{42}$ The subject of contradictory obligations is being debated currently within the realm of moral and legal philosophy. See generally Symposium, Conficts of Rights, 7 LEGAL THEORY 235 (2001) (presenting various solutions to the rights-conflict issue). Contemporary rights theorists generally have assumed that rights (and by implication, accompanying obligations) cannot conflict. See Claire Oakes Finkelstein, Introduction to the Symposium on Conflicts of Rights, 7 LEGAL THEORY 235, 235 (2001) ("There is . . . a perfectly good explanation for why [the issue of conflicting rights] has received so litthe attention; namely that contemporary rights theorists have generally assumed that rights cannot conflict."). Those who believe rights may conflict offer many solutions to the problem. See, e.g., Claire Oakes Finkelstein, Two Men and a Plank, 7 LEGAL THEORY 279, 288-306 (2001) (rejecting the assumption that if $A$ has a right to $X$, then she cannot also have a duty to refrain from $X$ ); Philip Montague, When Rights Conflict, 7 LEGAL THEORY 257, 277 (2001) (arguing that rights may conflict at a prima facie level, but these conflicts may be resolved on an all-things-considered level). I believe in the rights-specification theory, which does not allow for conflicting rights and obligations. However, a discussion of rights-conflict theory is outside the scope of this Comment and as such, for the purposes of this Comment, I must leave this statement as an assumption.

${ }_{49}^{4}$ See supra note 15 and accompanying text (outlining the reasons for using Hobbes's theory).

eign. 
cede some of its authority, I will also discuss Hobbes's theory of obligation and his idea of a natural limit to the life of the sovereign.

Having laid down this framework, in Part II, I will turn to the relationships that the commonwealths ${ }^{45}$ have with each other. From this description, and the previously laid foundation, I will present a preliminary version of "The Fundamental Law of International Relations." ${ }^{46}$ This is the law that imposes upon the municipal sovereign (or sovereign of a nation-state) an obligation to create an international sovereign (or international governing body) at certain times. ${ }^{47}$ This is a law of international relations, which allows us to show that treaty obligations that create international sovereigns are valid transfers of sovereign authority, and thus create a binding obligation on the municipal sovereign to obey the international sovereign.

Finally, in Part III, I answer potential objections to this theory. In this Part, I have two goals. First, I ensure that there are no internal inconsistencies with my use of the Hobbesian framework. Second, and more importantly, I argue that any potential objections cannot be supported by the Hobbesian text, but instead represent merely intuitive arguments against my theory. An analysis of these objections ultimately leads to a stronger theory of international relations, for it requires three corollaries to my original thesis: (1) the powers granted by the municipal sovereign to the international sovereign cannot exceed the powers granted the municipal sovereign by its subjects; (2) an international legal structure cannot be created if municipal states already have fallen back into the Hobbesian state of nature with respect to each other; and (3) the municipal sovereign must have the legal authority within its own nation's framework to enter into international treaties.

While my definition of "international sovereign" will become clearer throughout the Comment, it is important to make a preliminary note. By international sovereign, I do not mean "king of the world." The international sovereign is not the Leviathan. ${ }^{48}$ Rather, it

${ }^{45}$ For purposes of this Comment, I shall use the terms "commonwealth" and "sovereign state" interchangeably.

${ }^{46}$ This law, while based upon the Hobbesian text, is of my own invention and is not itself located within the text. See infra note 74 (noting that my theory is a "quasiHobbesian," not a strict Hobbesian theory.

${ }^{47}$ See infra note 48-49 and accompanying text (explaining the meaning of international sovereign).

${ }^{48}$ Leviathan was a large, terrifying marine animal. See Job 41:1 (describing the Leviathan). In one edition of Hobbes's Leviathan, the sovereign is illustrated as a Leviathan subsuming its subjects. ThOMAS HOBBES, LeVIaTHAN 71 (C.B. MacPherson ed., 
is an international legal structure to which various commonwealths have ceded some of their sovereignty. ${ }^{49}$ As I will show, this structure can be extremely limited in scope, and indeed oftentimes must be.

\section{BUILDING THE ANALYTICAL FRAMEWORK}

\section{A. A Review of the Hobbesian State of Nature and an Introduction to the Hobbesian Sovereign}

Hobbes writes that in the state of nature, every man has a right to everything. ${ }^{50}$ But the meaning of "right to everything" must be clarified. For if every man had a right to everything, surely all rights would be cancelled out and no man would have a right to anything. A better way of understanding what Hobbes was saying may be to assert that in the state of nature, all men have a privilege to everything. ${ }^{51}$

Professor Wesley Newcomb Hohfeld's rights analysis will help explain this. ${ }^{52}$ Professor Hohfeld presents his readers with four correlative relations. ${ }^{53}$ These are right-duty, privilege-no right, power-liability and immunity-disability. ${ }^{54}$ Rights, for which Hohfeld uses the synonym claims, are rights precisely because they contain correlative duties to do or refrain from doing something. ${ }^{55}$ In a Hohfeldian system, a claim

\section{Penguin Books 1968) (1651).}

${ }^{49}$ The European Union stands as an example of this international legal structure.

${ }^{50}$ See Thomas Hobbes, Leviathan, ch. xiv, para. 4 (Edwin Curley ed., Hackett Publ'g Co. 1994) (1651) ("[I]n such a condition [as exists in the state of nature] every man has a right to everything, even to one another's body.").

${ }^{51}$ In her book, Judith Jarvis Thomson also notes that a way to understand this portion of the Hobbesian text is to assert that all men have a privilege to everything. See JUDITH JARVIS THOMSON, THE REALM OF RIGHTS 50 (1990) ("There is no difficulty whatever if the natural rights one has in mind are, all of them, privileges."). However, Thomson goes on to declare that a privilege is simply a lesser form of a right. Id. at 5052. I think it better, for purposes of this Comment at least, to stay with the Hohfeldian categories as strictly delimitating rights from privileges. See infra text accompanying notes 52-61 (discussing Hohfeld's distinction between rights and privileges).

${ }^{52}$ Professor Hohfeld intended his categories to be utilized to provide a framework for analyzing basic conceptions of law. See Wesley Newcomb Hohfeld, Some Fundamental Legal Conceptions as Applied in Judicial Reasoning, 23 YALE L.J. 16 (1913) (“[T]he present article ... will discuss as of chief concern, the basic conceptions of the law,- the legal elements that enter into all types of jural interests."), reprinted in WESLEY NEWCOMB HOHFELD, FUndaMENTAL LEgal CONCEPTIONS AS APPLIED in JUdicial REASONING AND OTHER LEGAL ESSAYS 23 (Walter Wheeler Cook ed., 1923) [hereinafter HOHFELD, CONCEPTIONS].

${ }^{53}$ Id. at 36.

${ }^{54} \mathrm{Id}$.

${ }^{55}$ Id. at 38. For a theory of what it means to be under a duty, and hence what it means to have a claim, see THOMSON, supra note 51, at 61-78. 
in person $A$ as to person $B$ to $X$ necessarily implies that person $B$ has a duty to person $A$ to $X^{56}$ So in the state of nature, if all people had claims to all things, then all people would be under a duty to refrain from all things, and thus no man would have a claim to anything because he would have a duty to refrain by virtue of the claims held by others. $^{57}$ A privilege, on the other hand, implies a lack of a duty. ${ }^{58} \mathrm{~A}$ lack of duty in person $A$ as to person $B$ to $X$ implies a lack of claim of person $B$ as to person $A$ to $X$. This lack of claim Hohfeld terms a noright. $^{59}$ Applying this terminology to the Hobbesian state of nature, humans have a privilege as to everyone to everything and no person has a claim to anyone for anything. As such, each person has a no-right to everyone as to everything, which means that all the world is open to all persons, with the only question being who has the physical and mental ability to control a thing. This no-right in everyone is equivalent to what Hobbes deems to be the "liberty" of all people in the state of nature. ${ }^{60}$ Following this, what Hobbes deems to be the "right of nature" is the privilege to do anything that would preserve one's own life, using any means to do so. ${ }^{61}$

Since each person has a no-right to everyone as to everything, Hobbes's state of nature can be a harrowing place. No one has a claim against any other person, even for the protection of his or her own body. Hobbes calls this state of insecurity a state of war. It is important to note that a state of war in Hobbesian terms does not necessarily imply battle, but rather a state of insecurity. ${ }^{62}$

Under Hobbes's theory, humans, using their reasoning, ${ }^{63}$ quickly realize that the state of nature is not advantageous. From this, humans deduce the fundamental laws of nature to which all humans are bound. ${ }^{64}$ Among other things, these laws oblige humans to seek peace

${ }^{56}$ HOHFELD, CONCEPTIONS, supra note 52, at 37-38.

${ }^{57}$ See supra note 42 for a caveat as to the rejection of competing claims.

58 HOHFELD, CONCEPTIONS, supra note 52, at 38-39.

59 Id. at 39-41.

${ }^{60}$ HoBBEs, supra note 50, at ch. xiv, para. 2. Indeed, Hohfeld states, without reference to Hobbes, that the closest synonym of legal "privilege" is legal "liberty." HOHFELD, CONCEPTIONS, supra note 52, at 47.

${ }_{61}$ HOBBES, supra note 50 , at ch. xiv, para. 1.

${ }^{62}$ See id. at ch. xiii, para. 8 ("[S]o the nature of war consisteth not in actual fighting, but in the known disposition thereto during all the time there is no assurance to the contrary.").

${ }^{63}$ See HOBBES, supra note 50, at chs. i-xi (discussing the state of man and man's reasoning abilities).

${ }^{64}$ For a description of why humans are bound by the law of nature, see DAVID P. Gauthier, Logic of Leviathan: The Moral and Political Theory of ThOMas 
if they have hope of obtaining it (and when they cannot to use all helps and advantages of war), and if necessary to that end and so long as others are willing to do so, to lay down their rights to all things. ${ }^{65}$ Essentially, these laws tell humans that for their advantage, they should seek peace, and that the best way to do so is to lay down parts of their natural liberty. From these laws of nature, people find that the best way to ensure their security is to enter into a commonwealth. Hobbes describes entering into the commonwealth as follows:

The only way to erect such a common power . . . is [for men] . . . to appoint one man or assembly of men to bear their person, and every one to own and acknowledge himself to be author of whatsoever he that so beareth their person shall act, or cause to be acted . . . and therein to submit their wills, every one to his will, and their judgments, to his judgment. ${ }^{66}$

Here Hobbes is dictating that in laying down parts of their natural liberty with respect to each other, people ought to create a common power that can ensure peace. It is extremely important to note that the agreement to create the commonwealth is an agreement among the subjects exclusively. "A commonwealth is said to be instituted, when a multitude of men do agree and covenant, every one with every one . . ."67 The sovereign is not party to the covenant that creates the political commonwealth. Rather, the sovereign can be viewed as a third-party beneficiary to this social contract. ${ }^{68}$

HoBBES 35-40 (1969). While an extended discussion of why humans are bound by these laws of nature is outside the scope of this Comment, the Hobbesian text concisely states that the "LAW determineth and bindeth." HOBBES, supra note 50, at ch. xiv, para. 3 .

\footnotetext{
And consequently it is a precept, or general rule, of reason that every man ought to endeavour peace, as far as he has hope of obtaining it, and when he cannot obtain it, that he may seek and use all helps and advantages of war. The first branch of which rule containeth the first and fundamental law of nature, which is to seek peace, and follow it. The second, the sum of the right of nature, which is by all means we can, to defend ourselves.

From this fundamental law of nature, by which men are commanded to endeavour peace, is derived this second law: that a man be willing, when others are so too, as far-forth as for peace and defence of himself he shall think it necessary, to lay down this right to all things, and be contented with so much liberty against other men, as he would allow other men against himself.
}

HoвBES, supra note 50, at ch. xiv, paras. 4-5 (emphasis and footnote omitted). For a discussion of the laws of nature, see PLAMENATZ, supra note 15, at 179-90; HoWARD WARRENDER, The POltical Philosophy OF HobBes 48-79 (1957).

HOBBES, supra note 50, at ch. xvii, para. 13.

${ }^{67}$ Id. at ch. xviii, para. 1.

${ }^{68}$ Claire Finkelstein, Hobbes on Contract 40 (Sept. 2, 2000) (unpublished manuscript, on file with author) ("[T]he Social Covenant looks suspiciously like a third-party 
The characteristics of the sovereign created out of this covenant are similar to that of natural humans. Hobbes states:

A person is he whose words or actions are considered either as his own, or as representing the words or actions of another man, or of any other thing to whom they are attributed, whether truly or by fiction.

When they are considered as his own, then is he called a natural person; and when they are considered as representing the words and actions of another, then is he a feigned or artificial person.

Thus, the sovereign is considered an artificial person, and the fact that its actions represent the actions of others is all that differentiates it as an artificial person from natural entities. A conclusion from the fact that this is the only inherent difference between artificial and natural entities is that artificial persons are subject to the laws of nature and can be described just as Hobbes describes natural humans.

There is, however, another difference between the sovereign and natural men. This difference arises from the covenant between the subjects, rather than the internal characteristics of the sovereign. As David P. Gauthier states, "[s] overeign right is not merely the right to rule over other men. Every man [including artificial men] has this right by nature." ${ }^{70}$ What sets the characteristics of the sovereign apart from that of natural humans, Gauthier states, is the correlative obligation of the subjects. ${ }^{71}$ This correlative obligation is an obligation to obey the sovereign, thus giving it power over its subjects. ${ }^{72}$

Initially, one may believe that the most important characteristic of the sovereign is its absolute power. Read simply, the text states that the subjects shall authorize all the actions and judgments of the sovereign. $^{73}$ Hobbes's theory, however, does allow for a limitation of the sovereign's seemingly absolute powers. ${ }^{74}$

beneficiary contract: it is an agreement made among the citizens pertaining to the sovereign, of which the sovereign is not himself a member.").

69 HOBBES, supra note 50, at ch. xvi, paras. 1-2.

${ }^{70}$ GAUTHIER, supra note 64, at 99 (citations omitted).

"See id. at 100 ("For there can be no sovereign without subjects, and no subjects without obligation to obey.").

${ }^{72}$ See infra notes 80-89 and accompanying text (explaining in detail how the sovereign's power over its subjects is created).

73 HOBBES, supra note 50 , at ch. xviii, para. 1.

74 This assertion represents a tremendous departure from Hobbes's own intent. See GAUTHIER, supra note 64, at 133-39 (examining Hobbes's insistence upon an absolute sovereign). Nevertheless, while Hobbes's insistence upon an absolute sovereign is quite apparent, see HoBBES, supra note 50, at ch. xxix, para. 1 (stating that "want of absolute power" tends toward the dissolution of a commonwealth), I believe, and Gauth- 


\section{B. The Sovereign's Power and the Limitation of Those Powers}

Hohfeld's theory supports the idea that a sovereign of limited powers can be created. Recall that I have argued that in the state of nature, people have global privileges and correlative no-rights, but they do not have claims and correlative duties. ${ }^{75}$ In entering the commonwealth and covenanting with each other, however, all persons take on a certain duty and correlative claim. Imagine, for purposes of simplicity, a Europe consisting solely of Germany, France, and Italy. ${ }^{76}$ In creating a "European Union," the sovereign of Germany now has a duty ${ }^{78}$ to the sovereign of France to obey the sovereign of the European Union. ${ }^{79}$ Germany also has a separate duty to Italy to obey the European Union. Similarly, Italy has a claim against Germany that Germany obey the European Union. Italy and France are substituted with Germany, and, eventually, each Member State ${ }^{80}$ has two claims

ier writes, that a formal inquiry into Hobbes's work will lead to a conclusion that " $[t]$ he extent of the authorization granted to the sovereign determines the extent of sovereign right." GAUTHIER, supra note 64 , at 133 . This ability to limit the sovereign's powers will play a large role not only in defending my thesis, but also in adding a corollary to my theory of international relations. Further, it will serve to prevent the conclusion that an international sovereign must be a "king of the world."

Nevertheless, one must be careful not to equate my theory with one that Thomas Hobbes himself would endorse. Rather, I put forth a "quasi-Hobbesian" theory-one that I believe may be deduced from the Hobbesian text, even if Hobbes himself did not foresee it, and to which he would not subscribe. See E-mail from William Ewald, Professor of Law and Philosophy, University of Pennsylvania, to Eric Wilensky (Mar. 19, 2002, 21:39:26 EST) (on file with author) ("[Thomas Hobbes] himself holds . . . to . . . a theory of indivisible sovereignty; it's not clear that he'd agree that, if a member state cedes some of its sovereignty to the EU, it then remains (stricto sensu) a Hobbesian sovereign.").

75 Supra notes 50-61 and accompanying text.

${ }^{76}$ At this point in the Comment, I have not yet established that sovereigns can act as "men" and themselves enter into a Hobbesian contract with each other. As such, either accept as an assumption that they can, or view Germany, France, and Italy as the only three people in Europe and the sovereign they create known as the "European Union,"

${ }^{77}$ I use the term "European Union" in order to help conceptualize my argument. I do not use it to refer to the true "European Union."

${ }^{78}$ Though this covenant was made in the state of nature, it is still a valid covenant. See infra notes 95-96 (noting that the notion that covenants may create obligations in the state of nature is a contentious one, and referencing Warrender's theory on how this may be possible).

${ }^{79}$ While it is important to note that it is the sovereign engaging in these relationships, for linguistic ease I will refer to the "sovereign of Germany" simply as "Germany." I will regard similarly France, Italy, and the European Union. If, as per footnote 76, one is assuming Germany, France, and Italy are individual actors, they may be considered their own sovereigns.

${ }^{80}$ The term Member State is the European Union equivalent for the term "subject 
and two duties. Note that the Member States do not have a distinct duty to the European Union to obey it; rather they have a duty toward each other to obey the European Union. ${ }^{81}$ The question becomes how the European Union's power comes about if the covenant merely creates rights and duties between the Member States.

Hohfeld's third and fourth categories are power-liability and immunity-disability. ${ }^{82}$ A power is best described as the ability to change the legal status of another. ${ }^{83}$ A liability exists when your legal status may be changed by another's use of his power. ${ }^{84}$ To the contrary, a legal immunity is the freedom from the power of another. ${ }^{85}$ In other words, to hold an immunity from $A$ as to $X$ means that you are not subject to a change in legal status in relation to $X$ by $A$. However, if you hold a legal liability under $A$ as to $X$, then you are subject to a change in legal status by $A$ with regard to $X$. Thus, by obligating themselves to obey anything the sovereign does, the subjects now have a legal liability toward the sovereign and the sovereign has the power to change their legal status. The sovereign is the only entity within this union holding this power.

To make the point, we return to the three-member European Union. France says to Italy, "I covenant with you that I shall obey the European Union." It is what comes at the end of the sentence that determines the scope of the European Union's powers. If France states, "I covenant with you that I shall obey the European Union, renounce all my privileges that I previously had, will have further claims and privileges only as the European Union recognizes, and will give it unlimited powers," then the European Union is absolute and has the power to do anything as per France. France thus has a liability as to the European Union concerning every dynamic of its existence. ${ }^{86}$ The

of the European Union." See supra note 6 (defining "Member State" as the various members of the European Union).

${ }^{81}$ See supra note 68 and accompanying text (noting that the covenant creating the sovereign is taken up between the various subjects of the sovereign, and not between the subjects and the sovereign itself).

${ }_{82}$ HOHFELD, CONCEPTIONS, supra note 52, at 50-51.

${ }^{83}$ Id.

${ }^{84} \mathrm{Id}$.

${ }^{85}$ Id.

${ }^{86}$ It should be noted here that in Hobbesian theory, one cannot renounce one's privilege to self-defense. HовBES, supra note 50, at ch. xiv, para. 29. Thus, while in general subjects' liabilities are coupled with a duty to other subjects to obey the sovereign, under the Hobbesian view, in the case of a punishment, the subject is relieved of his duty to obey and may try to escape sentence. For a fascinating discussion of Hobbes's argument for the right of self-defense in the state of civil society, see Claire 
European Union's power comes about because, as an artificial man, it has a privilege to all things, ${ }^{87}$ whereas France has conditioned its privilege to all things on the will of the sovereign.

With a different ending to the sentence, however, it is possible to create a sovereign with only limited powers. Germany may say to France, "I covenant with you that I shall obey the European Union and renounce my privileges and confer upon it powers regarding criminal law." The European Union's powers are then limited to criminal law. As to civil law, administrative law, etc., the sovereign does not have the power to limit the privileges of the Member States.

Some may argue that this is a misconception. After all, the sovereign is merely a collection of all the citizens of the commonwealth, who themselves have a privilege as to everything. The sovereign, thus, by its very nature, has a privilege as to everything that cannot be limited. The subjects, however, are not creating privileges in the sovereign when they covenant with each other. Rather, they are creating powers-the ability to change legal status. By taking upon themselves not just a duty, but the specific duty to obey the sovereign, the subjects give the sovereign the power to change their legal status.

Returning to the European Union example, Italy says to Germany, "I covenant with you that I shall obey the European Union, renounce my privileges, and confer upon it powers regarding economics." Though the European Union may, by virtue of the sovereign as an artificial person, have a privilege to all things (including economics, crime, pollution, etc.), it only has powers with regard to economics. The existence of a power and immunity on the part of the sovereign, and a liability and disability on the part of the subject, are the defining characteristics of the sovereign. ${ }^{89}$

In limiting the privileges they agree to lay down, the subjects can limit the power of the sovereign. This does not contradict Hobbes's theory; it is merely an extension of it. Hobbes says: "[W] hen [his subjects] limit [the sovereign] in what, and how far, he shall represent them, none of them owheth more than they gave him commission to

Finkelstein, A Puzzle About Hobbes on Self-Defense, 82 PAC. PHIL. Q. 332 (2001).

${ }^{87}$ See supra note 69 and accompanying text (noting that the artificial man is similar to the natural man, including the characteristic of having privileges to all things).

${ }^{88}$ See GAUTHIER, supra note 64, at 99-100 (elaborating on the meaning of sovereign right and sovereign power).

${ }^{89}$ Alternatively, one may view a power as a liberty in the sovereign that none of its subjects has. See supra notes 53-61 and accompanying text (describing Hohfeld's rights analysis and elaborating on the meaning of the term "liberty"). 
act." ${ }^{90}$ As such, with the exception of imposing a punishment upon its subjects, ${ }^{91}$ a sovereign has power over all its subjects to the extent of the power granted to it by the initial covenant. The scope of the sovereign's powers and immunities depends on the covenant between citizens. While I have not disproved the auto-limitation theory yet, if international law is valid, then it is clear that Ireland, in Society for the Protection of Unborm Children (Ireland) Ltd. $v$. Grogan, ${ }^{92}$ had a duty to the other Member States to obey the Court of Justice, where the matter was properly within the jurisdiction of the court. ${ }^{99}$

\section{The Ends of Government and the Natural Limit to the Sovereign's Power}

The final building block to the Fundamental Law of International Relations is an analysis of the theory of obligation within the state of nature. This theory of obligation will lead toward the natural limit to the sovereign's power.

There is no justice or injustice in the state of nature. ${ }^{94}$ Given this, it is questionable whether there may be obligation in such a state, but I believe there may be and as such, will discuss Hobbes's theory of obligation as if it applies both in the state of nature and in a municipal commonwealth.

${ }^{9}$ HOBBES, supra note 50 , at ch. xvi, para. 14

${ }^{91}$ See supra note 86 and accompanying text (noting the Hobbesian caveat to subject's obligations to their sovereigns).

${ }^{92}$ See supra notes $32-40$ and accompanying text (discussing the Unborn Children case).

The free movement of services that is at issue in this case is within the court's jurisdiction. See TREATY OF AMSTERDAM, supra note 19, at art. 49 ("[R]estrictions on freedom to provide services within the Community shall be prohibited . . ..").

${ }^{94}$ See HOBBES, supra note 50, at ch. xiii, para. 13 ("To this war of every man against every man, this also is consequent; that nothing can be unjust. The notions of right and wrong, justice and injustice have there no place. Where there is no common power, there is no law: where no law, no injustice.").

${ }^{95}$ This, in fact, is considered a fundamental flaw in Hobbes's theory, for if there is no obligation, there can be no covenant and thus the original covenant creating the sovereign cannot be made. See GAUTHIER, supra note 64, at 59 ("Hobbes supposes that we escape from the state of nature, and enter political society, by covenant, but he can be interpreted as holding that covenants made in the state of nature are invalid.); PlAMENATZ, supra note 15, at 190-197 (discussing the making and keeping of covenants, specifically the initial covenant); WARRENDER, supra note 65, at 1-9 (discussing the questions left open in Hobbes's theory of obligation). Many theorists have attempted to reconcile this problem with the Hobbesian text. See GAUTHIER, supra note 64, at 58-60 (demonstrating how obligation may exist in the state of nature); WARRENDER, supra note 65, at 30-100 (discussing obligation in the state of nature).

${ }^{96}$ While an extended discussion of Hobbes's theory of obligation is outside the scope of this Comment, I will accept as an assumption that obligation may exist in the 


\section{Hobbes says of obligations:}

Right is laid aside either by simply renouncing it or by transferring it to another ... . And when a man hath in either manner abandoned or granted away his right, then is he said to be Obliged or Bound not to hinder those to whom such right is granted or abandoned from the benefit of it; and ... he ought, and it is his Duty, not to make void that voluntary act of his own....

Returning to the Hohfeldian categories, at least one claim and one duty will be created in a covenant. ${ }^{98}$ Hobbes considers fulfilling that duty to be an obligation." Germany says to Italy, "I will give you twenty dollars now, if you promise to give me twenty bottles of wine within two weeks," and Italy agrees. Once Germany gives Italy twenty dollars, Italy has a duty to Germany and is under an obligation to fulfill that duty. ${ }^{100}$

Only certain covenants are valid initially in the Hobbesian scheme ${ }^{101}$-and, in general, for those covenants to end there must be

state of nature, will base this assumption on Warrender's theory, and will utilize his framework.

${ }^{97}$ HOBBES, supra note 50, at ch. xiv, para. 7 (emphasis and citations omitted).

${ }^{98}$ A covenant is an agreement by which rights are mutually transferred, but one, or both, of the parties to the agreement performs his part at a later time. See HOBBES, supra note 50, at ch. xiv, para. 11 ("Again, one of the contractors may deliver the thing contracted for on his part, and leave the other to perform his part at some determinate time after ... and then the contract on his part is called a ... Covenant ...." (emphasis omitted)).

${ }^{99}$ See id. at ch. xiv, para. 7 ("And when a man hath . . . abandoned his rights ... then he is said to be obliged ... and it is his duty, not to make void that voluntary act of his own ...." (emphasis omitted)). Note that Hobbes makes a distinction between obligations in foro interno (those obligations that do not come from an external legal source) and in foro externo (those that do). Id. at ch. xv, para. 36. The breaking of obligations in foro interno is a vice, but not necessarily a crime. HOBBES, supra note 50 at ch. 15, paras. 35-37. Nevertheless, since in foro interno and in foro externo obligations are both subspecies of obligations, those under either type of obligation must see that it is undertaken. HOBBES, supra note 50 , at ch. xiv, para. 7.

${ }^{100}$ This would be true both in the state of nature and in a civil society. See HOBBES, supra note 50, at ch. $\mathrm{xv}$, paras. 36-41 (noting that laws of nature and laws of civil society oblige the same result); see also WARRENDER, supra note 65, at 53-79 (explaining how obligations in the state of nature, though subject to the satisfaction of validating conditions, are not unlike the obligations of civil society). Even if the covenant were made in the state of nature, Italy would be bound in foro interno by the laws of nature to fulfill its covenant.

${ }^{101}$ See HoBBes, supra note 50, at ch. xiv, paras. 9-33 (giving a framework for the evaluation of when a covenant is valid).

A covenant is valid at the time when it is made, if it is a covenant to do something permitted by law, and if both parties have accepted it, and further, if it is not a covenant to do something known to be impossible, nor one resigning the right of self-defence, nor stipulating obligations to a person un- 
either performance or forgiveness. ${ }^{102}$ There are certain ways, however, that covenants are invalidated, without either performance or forgiveness. A properly created covenant can be invalidated if the requisite condition of mutual trust degenerates:

If a covenant be made wherein neither of the parties perform presently, but trust one another, in the condition of mere nature ... upon any reasonable suspicion it is void; but if there be a common power set over them both, with right and force sufficient to compel performance, it is not void.

The cause of fear which maketh such a covenant invalid must be always something arising after the covenant made (as some new fact or other sign of the will not to perform), else it cannot make the covenant void. For that which could not hinder a man from promising, ought not to be admitted as a hindrance of performing. ${ }^{103}$

Thus if one party to the covenant reasonably suspects that a second party will not fulfill its obligations under the covenant, then the covenant becomes void. For example, in our Hobbesian state-ofnature Europe, France and Italy have just covenanted between themselves. France agreed to dispose of Italy's garbage for the next month, and in exchange Italy agreed to supply France with wine. Both France and Italy now have a claim against each other and a duty to each other. However, something may happen such that Italy no longer trusts that France will dispose of its trash and fears that France instead will stop disposal after one week. ${ }^{104}$ Since Italy reasonably (as judged by Italy) suspects that France will not complete its obligations under the covenant, the covenant is void. Since the covenant would have disappeared, Italy then may stop providing wine to France without violating its obligation.

In the state of nature, this happens quite frequently. Since each human is the judge of his or her own opinion, ${ }^{105}$ most people likely would consider their suspicions to be reasonable, and covenants ac-

known to the party obliged, nor, finally, a covenant to give or do something, the right to which has previously been covenanted away.

WARRENDER, supra note 65 , at 35.

${ }^{102}$ See HoBbes, supra note 50, at ch. xiv, para. 26 ("Men are freed of their covenants two ways; by performing or by being forgiven.").

${ }^{103}$ HOBBES, supra note 50, at ch. xiv, paras. 18, 20.

${ }^{104}$ Whatever it was that made Italy suspicious of France must be a condition that arose after the creation of the covenant.

${ }^{105}$ See HoBBES, supra note 50 , at ch. xiv, para. 18 (" $[\mathrm{I}] \mathrm{n}$ the condition of mere nature ... all men are equal and judges of the justness of their own fears ...."). 
cordingly would be voided. In civil society, however, this cannot happen. Consider again our European Union of Italy, France, and Germany. Since this European Union now controls the sword, and now can enforce all of the Member State's covenants, a fear that one Member State will not perform its covenant is unreasonable. ${ }^{106}$ Thus it seems that covenants of mutual trust cannot be made invalid as long as the sovereign exists.

There is, however, a particular covenant that may be invalidated in civil society under certain circumstances. That covenant is the original covenant that created the commonwealth. Hobbes says of the end of commonwealths, "the end of this institution is the peace and defence of them all." 107 If the commonwealth stops providing the peace and defense of the subjects so that the subjects justly suspect that their fellow subjects will stop performing their obligations under the original covenant, the commonwealth comes to an end. ${ }^{108}$

One may argue that this seems contrary to Hobbes's ideas. Hobbes seems to say that no one may challenge the power of the sovereign. $^{109}$ However, the covenant that created the sovereign, which is the basis of the sovereign's power, is a covenant between the subjects of the commonwealth. ${ }^{110}$ The sovereign is not a party to the cove-

${ }^{106}$ See HobBes, supra note 50, at ch. xiv, para. 19 ("But in a civil estate, where there is a power set up to constrain those that would otherwise violate their faith, that fear is no more reasonable; and for that cause, he which by the covenant is to perform first is obliged to do so.").

${ }^{907}$ HOBBES, supra note 50 , at ch. xviii, para. 8.

108 Howard Warrender explains:

The subject may ... legitimately ask whether the sovereign has in fact the power to protect him ....

... [T]he subject is entitled to act upon suspicion, or in prevention of danger provided that he sincerely considers his fears for his life to be reasonable. ... [T] [Te civil law provides no protection from the sovereign's lack of power ...

... [I]f the citizen should claim exemption from [an] obligation on the ground that he suspects that the sovereign has not the power to enforce the agreement and then on the ground that his fellow citizen is not to be relied upon, it would appear that Hobbes would have to concede such a claim .... WARRENDER, supra note 65, at 116-17.

${ }^{109}$ See, e.g., HOBBES, supra note 50, at ch. xviii, paras. 4-20 (discussing the superiority of proclamations of the sovereign and their immunity to challenge by the subject). But see $i d$. at ch. xxi, para. 21 ("The obligations of subjects to the sovereign is understood to last as long, and no longer, than the power lasteth by which he is able to protect them.").

${ }^{110}$ See supra Part I.B (explaining how subjects create the covenant that empowers or constrains the sovereign). 
nant. ${ }^{111}$ The duties and claims that exist regarding obedience to the laws of the sovereign are in relation to the subjects. For example, the sovereign of the now-troubled European Union has become lethargic. Germany suspects that France no longer will obey the European Union. Further, it suspects the European Union no longer will compel France to obey. As long as its suspicions are reasonable, ${ }^{112}$ Germany's duty to the Member States to obey the European Union is extinguished. Accordingly, Germany now may no longer respect the European Union's authority without violating its duty owed toward the other Member States.

Accordingly, all sovereigns only will take actions that maintain a sense of security in society so that no subject can suspect justly that the sovereign no longer will oblige other subjects to maintain their covenants. This is merely an action for survival.

\section{The State of Unstable Security and the (Preliminary) FUNDAMENTAL LAW OF INTERNATIONAL RELATIONS}

\section{A. In What Type of State Do Commonwealths Exist as to Each Other?}

1. The Possibility of International Agreement in the State of Nature

Hobbes's description of the state of nature is a state where life is "solitary, poor, nasty, brutish, and short."113 Intuitively, this does not seem to describe the current situation between states today. After all, states already have international agreements among one another, showing that while not ceding sovereign authority, they do engage in arms-length relationships that do not exist in the Hobbesian state of nature.

Both Gauthier and Warrender deal with this issue. ${ }^{114}$ The important passage in the Hobbesian text is as follows:

Nature hath made men so equal ... that ... when all is reckoned to-

${ }^{111}$ See supra note 68 and accompanying text (noting that the sovereign can be viewed as a third-party beneficiary to a third-party social contract).

${ }^{112}$ Since a sovereign was created, Germany's suspicion is reasonable only to the extent it is true.

${ }^{119}$ HOBBES, supra note 50, at ch. xiii, para. 9. I will refer to this state as the "Hobbesian SPNBS state of nature."

${ }^{114}$ See GAUTHIER, supra note 64, app. at 207-12 ("Hobbes recognizes that the state of nations is more tolerable than the condition of individual men in mere nature."); WARRENDER, supra note 65, at 118-120 ("[States'] position in the past, at least, has not corresponded exactly with that of Hobbes's individuals in the State of Nature."). 
gether the difference between man and man is not so considerable as that one man can thereupon claim to himself any benefit to which another may not pretend as well as he. For as to the strength of body, the weakest has strength enough to kill the strongest, either by secret machination, or by confederacy with others that are in the same danger with himself.

And as to the faculties of the mind ... I find yet a greater equality amongst men than that of strength. ${ }^{115}$

The problem that both Gauthier and Warrender point out is that the equality that Hobbes describes in the Hobbesian SPNBS state of nature does not seem to exist when civil societies have been formed. ${ }^{116}$ Nevertheless, both argue that this time of inequality may be ending, Gauthier specifically pointing to the increase in nuclear armament. ${ }^{117}$ I argue that this time is already at an end, if it ever existed at all. Further, I believe Gauthier and Warrender are wrong to concentrate on military power.

While Leviathan concentrates on military threats, ${ }^{118}$ it must be read as a document that may apply in the twenty-first century as well as the seventeenth. We live in a world different from the world that Hobbes knew in the seventeenth century. As I previously noted, the main characteristic of the state of nature is insecurity, not battle. ${ }^{119}$ Hobbes was greatly influenced by the Thirty Years' War and the English Civil War. ${ }^{120}$ Economic, environmental, and cultural insecurity would pale

115 HOBBES, supra note 50, at ch. xiii, paras. 1-2.

116 See GAUTHIER, supra note 64, app. at 207 (describing the "state of nations" as "lack[ing] the fundamental equality Hobbes finds in the State of Nature."); WARRENDER, supra note 65, at 198 (contrasting the unequal power of states with the equal power of individuals).

${ }^{11}$ See GAUTHIER, supra note 64, app. at 207 ("The advent of nuclear weapons is, however, bringing the state of nations nearer to the true Hobbesian State of Nature.").

${ }^{118}$ Hobbes states:

But though there had never been any time wherein particular men were in a condition of war one against another, yet in all times kings and persons of sovereign authority, because of their independency, are in continual jealousies and in the state and posture of gladiators, having their weapons pointing, and their eyes fixed on one another, that is, their forts, garrisons, and guns upon the frontiers of their kingdoms; and continual spies upon their neighbours, which is a posture of war.

HOBBES, supra note 50, at ch. xiii, para. 12.

${ }^{119}$ Supra note 62 and accompanying text.

${ }^{120}$ See William Ewald, Comparative Jurisprudence (I): What Was It Like to Try a Rat?, 143 U. PA. L. REV. 1889, 1933 (1995) (positing that Hobbes's experience during the Thirty Years' War "undoubtedly . . . left its mark on the theory of sovereignty in the Leviathan."); Rudy Wiebe, Land, Language, and Law, 63 SASK. L. REV. 29, 30-31 (2000) (noting that "Hobbes's thinking was strongly affected by the social chaos created by 
in comparison to militaristic insecurity in his time.

In the twenty-first century, insecurity includes economic, environmental, media, and cultural insecurity, among others. The Hobbesian text may be and must be read to account for this. If an OPEC nation decided to suspend oil production, the United Kingdom might spin into a deep recession. If a large industrial country did not put caps on the production of chlorofluorocarbons (CFCs), the entire world may become uninhabitable for humans. One may think of any number of possibilities, and the insecurity conjured up by these examples are twenty-first-century substitutes for the militaristic insecurity of the seventeenth century. Based on these insecurities, a country the size and strength of Afghanistan, Oman, or Israel can create extremely threatening situations for powerful countries like China, Russia, or the United States. The current state of relations between states includes the equality and accompanying ability to harm as required to fall within a Hobbesian state of nature. ${ }^{121}$ Although not obvious at first, this shows that Hobbes's state of nature can allow for the international agreement that exists today. As proponents of the auto-limitation theory describe all treaties, many of these agreements are "mere declarations of . . . proposed future conduct," for there is no sovereign with the power to enforce them. ${ }^{122}$

\section{The State of Unstable Stability}

As discussed above, obligation may exist in the state of nature, although in an extremely limited form. ${ }^{123}$ Given this, one can describe the state of nature based upon how readily entities within it come to believe that others will not fulfill their covenant. As such, one can conceive of a "utopian" state of nature in which individual entities never believe that others will breach their covenants, and therefore no sword is necessary. While purely theoretical, this "utopia"124 constitutes an extreme against which to contrast the Hobbesian SPNBS state

the English Civil War"); see also PlaMENATz, supra note 15, at 116 (describing Hobbes's time as a time of "civil strife and war").

${ }^{121}$ See supra note 115 and accompanying text (describing the equality (and related ability to harm) requisite to enter into the Hobbesian state of nature).

122 HART, supra note 10 , at 224.

123 See supra notes 94-106 and accompanying text (showing that obligation exists in the state of nature and explaining its fragility in such a state).

${ }^{124}$ I use the term "utopia" simply as a name for a fictional state of nature where covenants can be enforced without a sovereign. I do not use it in any philosophical sense. 
of nature, or a state in which entities never believe others will fulfill their covenants. ${ }^{125}$ Just to the right of the Hobbesian SPNBS state of nature and to the left of "utopia" in Figure 1, there exists a state that can be labeled an "unstable stability." This state can be characterized as one in which covenants may be invalidated based upon a belief that another covenanting party may not fulfill its obligation, yet one where this belief is not a foregone conclusion-a state where entities try to avoid that belief altogether.

\section{Figure 1: Variances of the State of Nature}

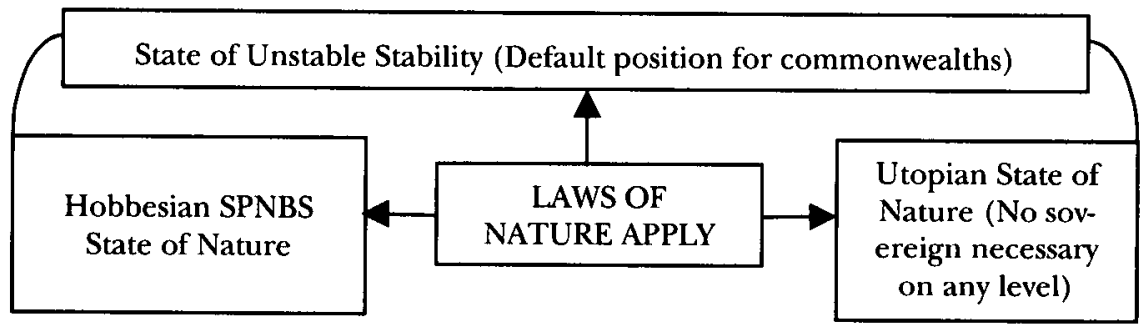

This state of unstable stability is fully compatible with Hobbes's theory, though more plausible on an international level than an individual level. ${ }^{126}$ It may be that at some point ${ }^{127}$ states come to realize that the insecurity is overwhelming and an international sovereign power is needed. The municipal sovereigns then would be moving from a state of unstable stability to a state of nature, and would form a new international sovereign.

${ }^{125}$ HoBBES, supra note 50 , at ch. xiii, para. 9.

${ }^{126}$ Gauthier suggests that the Cold War might be the most pronounced example of this. See GaUTHIER, supra note 64, app. at 207 ("Hobbes would have approved our phrase cold war, it expresses well what he took to be the permanent relationship of nations. Hobbes recognizes that the state of nations is more tolerable than the condition of individual men in mere nature.").

${ }^{127}$ In the case of the European Union, this point was World War II. Grossman and Bradlow see World War II as the impetus for many international organizations.

The Second World War provided members of the international community with a powerful and tragic lesson in the dangers inherent in an international legal order based upon a notion of absolute sovereignty. The contemporary international order severely limited the ability of the international community to intervene in the internal affairs of sovereign states. This lesson provided the impetus for the creation of new international organizations. The new organizations were still organized around the principle of sovereignty, but they were given some ability to compel member states to comply with their rules and decisions.

Grossman \& Bradlow, supra note 13, at 2. 
Since the utopian state, the state of unstable stability, and the Hobbesian SPNBS state of nature are all variants of the state of nature, the laws of nature would apply in all cases. Thus, we may proceed to consider when and how states are required to enter into international agreements ceding their authority.

\section{B. The Fundamental Law of International Relations}

Hobbes, speaking of the end of commonwealths, writes:

The obligation of subjects to the sovereign is understood to last as long, and no longer, than the power lasteth by which he is able to protect them .... The end of obedience is protection, which, wheresoever a man seeth it, either in his own or in another's sword, nature applieth his obedience to it, and his endeavour to maintain it. And though sovereignty, in the intention of them that make it, be immortal, yet is it in its own nature, not only subject to violent death by foreign war, but also through the ignorance and passions of men it hath in it, from the very institution, many seeds of a natural mortality by intestine discord. ${ }^{12}$

Thus, for their own survival, commonwealths must do all they can to preserve a sense of security within their own borders. Since the Laws of Nature dictate that one must do what is necessary for one's own survival, ${ }^{129}$ this is a requirement of that law. Given this premise, consider the second law of nature:

[T] hat a man be willing, when others are so too, as far-forth as for peace and defence of himself he shall think it necessary, to lay down this right to all things, and be contented with so much liberty against other men, as he would allow other men against himself. ${ }^{130}$

Combining this fundamental law with the above premise produces a preliminary version of what I term the Fundamental Law of International Relations:

When a municipal sovereign sees that its commonwealth is tending toward the Hobbesian SPNBS state of nature from the state of unstable stability with respect to other states, so long as the municipal sovereign deems necessary, and so long as other sovereigns are willing to do so, it must lay down its own sovereignty to create an international sovereign.

${ }^{128}$ HOBBES, supra note 50, at ch. xxi, para. 21 (emphasis added).

${ }^{129}$ See HOBBES, supra note 50, at ch. xiv, para. 3 ("A law of nature is a ... general rule ... by which a man is forbidden to do that which is destructive of his life ...."); see also WARRENDER, supra note 65, at 48-79 (discussing the laws of nature); supra note 65 and accompanying text (discussing the laws of nature).

${ }^{130}$ HoBbES, supra note 50 , at ch. xiv, para. 5. 
This "Fundamental Law of International Relations" dictates when a sovereign must cede a portion of its authority. It does not dictate when a sovereign cannot cede a portion of its own authority. In fact, so long as the initial covenant did not place any limitations on the municipal sovereigns' ability to covenant away their authority, ${ }^{131}$ municipal sovereigns may cede their authority at any time. ${ }^{132}$ Thus, even if states are firmly within the state of unstable stability, they may cede portions of their authority.

To explain, let us return to another hypothetical three-country Europe. Suppose Luxembourg has been the dominant power in a Europe containing Luxembourg, the Netherlands, and Belgium. Luxembourg has built up a nuclear arsenal capable of destroying the other two commonwealths within seconds. Throughout their history, however, all three commonwealths have entered into treaties to promote military cooperation among them. Yet, in recent years, the Netherlands has been building up its subversive capabilities and now possesses a credible threat to both Belgium and Luxembourg. In turn, Belgium has built up a nuclear arsenal. The commonwealths no longer trust each other and are tending toward the state of nature. There is often bloodshed and battle between the powers, and it seems the war is at a stalemate. Since the commonwealths are all under a duty to seek peace whenever possible, ${ }^{193}$ they have all tried disposable means of doing so, but there is a general consensus that only a common sovereign could stabilize the situation. So long as each of the other commonwealths is willing to do so, ${ }^{194}$ each commonwealth is under a duty, in foro interno, ${ }^{135}$ to create an international sovereign.

${ }^{131}$ See infra Part III.E (discussing this corollary to the Fundamental Law of International Relations).

${ }^{132}$ See supra Part I.B (explaining how sovereign authority may be limited); infra notes 158-66 and accompanying text (showing how an initial covenant may limit the sovereign's ability to covenant away its own authority).

${ }^{193}$ See supra notes 64-69 and accompanying text (explaining that the laws of nature oblige humans to seek peace whenever possible and that municipal sovereigns are subject to the laws of nature).

${ }_{194}^{19}$ If any of the commonwealths are not willing, then there would be no covenant.

${ }^{195}$ The laws of nature only bind in foro interno. See supra note 99 for a discussion of obligations in foro interno. 


\section{Figure 2: When the Fundamental Law of International Relations Applies}

Sovereigns PERMITTED to enter into an international covenant

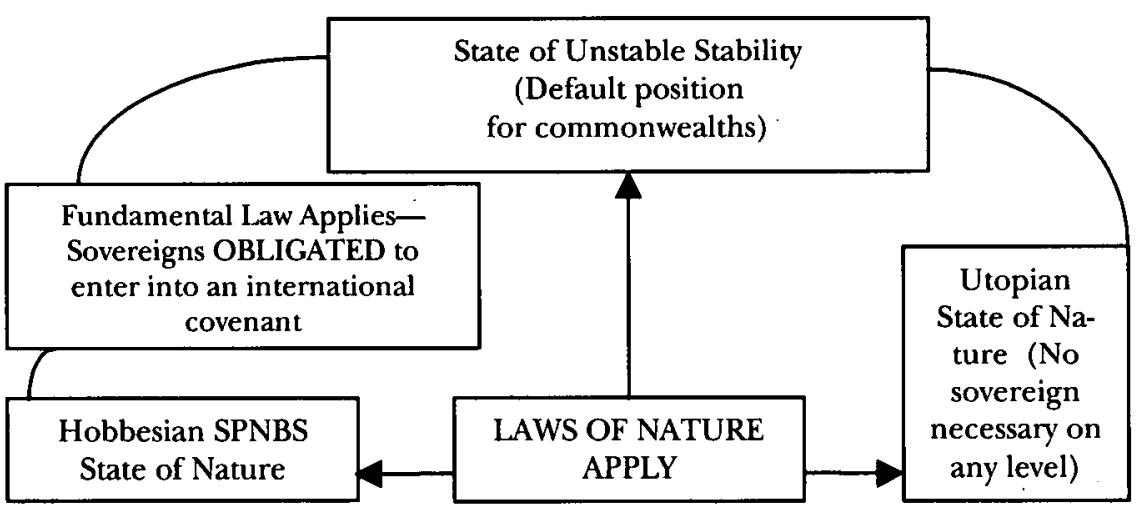

Considering the potential limitation of the sovereign's scope of power, ${ }^{136}$ the municipal commonwealths may move into an international commonwealth as to pollution, for example, while maintaining a state of unstable stability regarding defense. For example, the commonwealths of the world may realize that each country poses an extreme risk with regard to the production of CFCs, and feel the need for an international sovereign, while still feeling they can negotiate with each other on an economic or militaristic level.

\section{OBJECTIONS TO THE THESIS AND COROLLARIES TO THE FUNDAMENTAL LAW OF INTERNATIONAL. RELATIONS}

\section{A. The Indivisibility of Sovereign Right ${ }^{137}$}

After finishing his discussion of the rights of the sovereign, Hob-

${ }^{196}$ See supra Part I.B (discussing the feasibility of creating a sovereign of limited powers).

${ }^{137}$ As has been shown, Hobbes's terminology and the terminology of Hohfeld do not match immediately. Hobbes's term "right" can be analogized to Hohfeld's term "privilege." See supra notes 52-61 (reviewing Hohfeld's rights analysis and comparing it with Hobbes's state of nature). Further, when Hobbes speaks of sovereign rights, we can assume him to mean privileges of the sovereign that match up with privileges laid down by the subjects, hence sovereign powers. See GAUTHIER, supra note 64, at 126-28 (explaining the meaning of sovereign right within the Hobbesian text). For the sake of simplicity, I will use the term "right" in this section, as this is what Hobbes uses in his text. 
bes speaks of those rights as indivisible:

These are the rights which make the essence of sovereignty ... [and] are incommunicable and inseparable. The power to coin money, to dispose of the estate and persons of infant heirs, to have preemption in markets, and all other statute prerogatives may be transferred by the sovereign, and yet the power to protect his subjects be retained. But if he transfer the militia, he retains the judicature in vain, for want of execution of the laws; or if he grant away the power of raising money, the militia is in vain; or if he give away the government of doctrines, men will be frighted into rebellion with the fear of spirits. And so if we consider any one of the said rights, we shall presently see, that the holding of all the rest will produce no effect, in the conservation of peace and justice, the end for which all commonwealths are instituted. And this division is it, whereof it is said a kingdom divided in itself cannot stand. ${ }^{138}$

This suggests that the powers cannot be divided. Hobbes considers the division of sovereign power as a contribution to the dissolution of the commonwealth: "There is a sixth doctrine plainly and directly against the essence of a commonwealth, and it is this: That the sovereign power may be divided. For what is it to divide the power of a commonwealth, but to dissolve it; for powers divided mutually destroy each other." To address this, we may look once again to the Hohfeldian terms and to our three-country Europe. The sovereign governments of Luxembourg, Belgium, and the Netherlands ${ }^{140}$ have just covenanted with each other to create the European Union, which will have powers over the economic policy between the three commonwealths. We know that if Luxembourg, Belgium, and the Netherlands were individuals, this creation would be valid. Belgium would have a duty to Luxembourg and the Netherlands to obey the European Union, but only as to that power given to it. Within that area, the European Union would be sovereign. The question is, in entering into this covenant, are Belgium, Luxembourg, and the Netherlands invalidly dividing their sovereign powers?

Hobbes says of those who create the covenants: "[E]very subject is by this institution author of all the actions and judgments of the sovereign instituted." ${ }^{141}$ Thus, even if the Netherlands were to covenant with Belgium and Luxembourg, it would create a sovereign of whose

${ }^{138}$ HOBBES, supra note 50, at ch. xviii, para. 16.

139 Id. at ch. xxix, para. 12.

140 Similar to the previous European Union example, although I am referring to the sovereigns of each government, I will drop the term "the sovereign of" for linguistic simplicity.

${ }^{141}$ HOBBES, supra note 50 , at $\mathrm{ch}$. xviii, para. 6. 
acts it itself is an author. To its subjects, this new sovereign is the same thing as the Netherlands itself. For when the sovereign acts, the Netherlands acts as well. Hobbes's statement concerning the invalidity of dividing rights only concerns giving up one's rights without creating a sovereign whose exercise of those rights would be one's own. While, in one of the subheadings of chapter eighteen, Hobbes writes, "The Consequences to such Institution are I. The Subjects cannot change the form of government," ${ }^{142}$ nowhere in the book does he mention an inability of the sovereign to change the form of government. From this explicit statement that the subjects may not change the form of government and the conspicuous absence of any mention of the sovereign changing the form of government, one may conclude that Hobbes meant to allow the sovereign to change the form of government. In creating a new sovereign and vesting some sovereign rights in the new sovereign, the old sovereign is merely changing the form of its government. Further argument can be made from the following passage: "If a monarch shall relinquish the sovereignty, both for himself and his heirs, his subjects return to the absolute liberty of nature .... For then there can no heir be known, and consequently no subjection be due." In the case of international law, a sovereign has not relinquished its sovereignty over its subjects. It has just created a new form of enforcement. Since the sovereign power still exists, the subjects cannot have a reasonable fear that the sovereign will not be able to protect them, and thus their covenants with each other to obey the sovereign remain intact.

\section{B. The Theory That Power Must Emanate from the People}

Another argument may be similar to the one presented to the German court by challenging the European Union Treaty in the Maastricht case. ${ }^{144}$ Before Germany ratified the Treaty of Maastricht, ${ }^{145}$ twenty separate constitutional challenges were filed. ${ }^{146}$ The basic rationale of the complaints was that approval of the treaty would violate

142 Id. at ch. xviii, paras. 2-3 (emphasis added).

143 Id. at ch. xxi, para. 23.

144 Brunner v. European Union Trealy, [1994] 1 C.M.L.R. 57, 72 (BVerfGE 1993) (F.R.G.) (noting the argument that an individual's "right to participate in the exercise of state power" is "substantially diminished because the Union Treaty 'transfers' essential competences of the Bundestag to institutions of the European Communities").

145 This treaty, which established the European Union in its current three-pillar form, is the TEU TREATY, supra note 19.

146 Bermann ET AL., SUPPlement, supra note 9, at 123. 
the German constitutional principle ${ }^{147}$ that "all state power emanates from the people." 148 The idea, set forth in Hohfeldian terms, is that if the subjects covenanted together to create powers in a specific sovereign, the sovereign would violate the original covenant if it vested those powers in someone else. In other words, the subjects had covenanted with one another to obey sovereign $X$. Intuitively, it does not seem right that they should be obligated to obey anyone other than sovereign $X$.

The answer to this objection, which comes not from the text, but from principle, is quite similar to the above answer-that the power is still emanating from the people. The sovereign was not a party to the original covenant; the people were the only parties to the covenant, and all they agreed to do was obey the sovereign. Suppose that after Belgium covenants with the Netherlands and Luxembourg, the European Union creates a court whose jurisdiction includes all the subjects in the commonwealths of Belgium, the Netherlands, and Luxembourg in antitrust cases. Though the citizens now are subject directly to this new court, in Hobbesian terms they are really subject to the initial sovereign's power. Again:

[B] ecause every subject is by this institution author of all the actions and judgments of the sovereign instituted, it follows that, whatsoever he doth, it can be no injury to any of his subjects, nor ought he to be by any of them accused of injustice.... [B]y this institution of a commonwealth every particular man is author of all the sovereign doth ....

Thus, no matter what this new court does, the Netherlands may not claim that the new court's actions are not its own. As such, the subjects of the Netherlands are in theory still subject to the sovereign, though in a new setting. The rights of the sovereign were not divided or even taken away from it-they were just recast in a new light. Since the Netherlands' power stems from the subjects of the commonwealth of the Netherlands and the European Union's power stems from the

${ }^{147}$ Article 38 of the German Basic Law provides that elected legislative officials "shall be representatives of the whole people." DONALD P. KOMMERS, THE CONSTITUTIONAL JURISPRUDENCE OF THE FEDERAL REPUBLIC OF GERMANY, app. at 512 (2d ed. 1997); see also Brunner, [1994] 1 C.M.L.R. at 72 (interpreting the claim as the "right to participate in the exercise of state power").

148 BERMANN ET AL., SUPPLEMENT, supra note 9, at 123. The German court "reserved ... the right to verify whether and to what extent the institutions may have exceeded powers accorded them," and concluded that "the European Union lacks the power to define finally its own powers and competences or to require German authorities to implement them if the Constitutional Court rules otherwise." Id. at 124.

${ }^{149}$ HOBBES, supra note 50, at ch. xviii, para. 6. 
sovereign of the Netherlands, the base of power is still the subjects of the commonwealth of the Netherlands.

One may object and say that if the subjects are now going to be subjects of a new sovereign, they should approve of the new sovereign by way of a referendum. After all, the legal status of the subjects is changing, as they are now liable to a new sovereign. Remember, however, that at the creation of the commonwealth, the subjects created a sovereign with certain powers, or the ability to change its subject's legal status. All that a sovereign does by entering into this international covenant is change the legal status of its subjects. Providing the subjects enabled the sovereign to engage in this type of international treaty, the sovereign is well within its powers to take this action.

One caveat becomes clear from this argument. The sovereign may not cede more authority than it was provided originally under the subjects' covenants between each other. I have been arguing that even if the sovereign cedes its authority to a new sovereign, the subjects are still obeying the original sovereign so that the new sovereign's power still emanates from the people. This argument falls apart if the new sovereign has powers and privileges not granted to the original sovereign. Thus, if the sovereign's powers in Belgium were limited to regulating economic activities, it may not covenant to create a new sovereign whose powers and privileges include regulating the criminal law system. This holds true even if those with whom it is covenanting have powers and privileges to regulate the criminal law system in their own commonwealth. In other words, the scope of power of an international sovereign may only be as wide as the scope of power of the weakest sovereign that created it. Therefore, we get an amended Fundamental Law of International Relations:

When a municipal sovereign sees that its commonwealth is tending toward the Hobbesian SPNBS state of nature from the state of unstable stability with respect to other states, so long as the municipal sovereign deems necessary, and so long as other sovereigns are willing to do so, it must lay down its own sovereignty to create an international sovereign whose powers will not exceed the powers granted the municipal sovereign by its subjects.

\section{The Specific Problem of a Defeated Sovereign}

One challenging the validity of international law may use yet another passage to support his argument: "If a monarch subdued by war render himself subject to the victor, his subjects are delivered from 
their former obligation, and become obliged to the victor." ${ }^{150}$ This passage appears in Leviathan under the heading "In case the Sovereign render himself Subject to another." ${ }^{\text {"151 }}$ As stated above, ${ }^{152}$ the state of war does not necessarily apply to actual battle, but can apply to any state of insecurity. One may claim, then, that if the sovereign believes that the only way to maintain peace is to create an international sovereign, the sovereign is subjecting itself to another and its subjects are no longer obliged to obey it.

However, this passage mentions the word "victor," and from that, one may conclude that whatever war there was, be it an actual battle, or a war of culture, language, etc., one side came out clearly above another. If the battle has come this far, however, the subjects of the sovereign already have been relieved of their duty toward each other to obey the sovereign and are thus back in the Hobbesian SPNBS state of nature as to each other. ${ }^{159}$ If Belgium is in battle with Luxembourg and Belgium is about to be defeated, it ceases to exist. By its inability to defend its subjects, Belgium has allowed for them reasonably to believe that the other subjects no longer will obey the original covenant. This represents a relinquishing of Belgium's power over its subjects so that Hobbes's passage regarding the relinquishing of sovereign power now applies. ${ }^{154}$ The subjects of the defeated sovereign are no longer subject to the defeated sovereign and have returned to the Hobbesian SBNBS state of nature and Hobbes's passage regarding common-

${ }^{150}$ Id. at ch. xxi, para. 25.

151 Id

152 Supra note 62 and accompanying text.

${ }^{153}$ Realistically, this return to the Hobbesian SPNBS state of nature would be quite brief. As per Hobbes's passage on commonwealth by acquisition, the victorious sovereign would covenant with each of the defeated sovereign's subjects and they would become subjects of it. He states:

A commonwealth by acquisition is that where the sovereign power is acquired by force; and it is acquired by force when men singly (or many together by plurality of voices) for fear of death or bonds to authorize all the actions of that man or assembly that hath their lives and liberty in his power.

And this kind of dominion or sovereignty differeth from sovereignty by institution only in this, that men who choose their sovereign do it for fear of one another, and not of him whom they institute, but in this case they subject themselves to him they are afraid of. In both cases they do it for fear.... ...

It is not . . victory that giveth the right of dominion over the vanquished, but his own covenant.

HOBBES, supra note 50 , at ch. $\mathrm{xx}$, paras. $1-2,11$.

${ }^{154}$ See supra notes 107-12 and accompanying text (setting out the ends of sovereign power). 
wealth by acquisition takes precedence.

Thus, the challenge is superficial; states that are tending toward the Hobbesian SPNBS state of nature still have the ability to create an international sovereign. However, the challenge adds a second corollary to the Fundamental Law of International Relations-a corollary that refines its applicability. It shows that this law can operate only where there are municipal sovereigns, and thus there can be no international law once states fall back into the Hobbesian SPNBS state of nature. Figure 3 reflects this concrete boundary.

Figure 3: When the Fundamental Law of International Relations Applies (Revised) and When Valid International Law

\section{May Not Be Created}

Sovereigns PERMITTED to enter into an international covenant

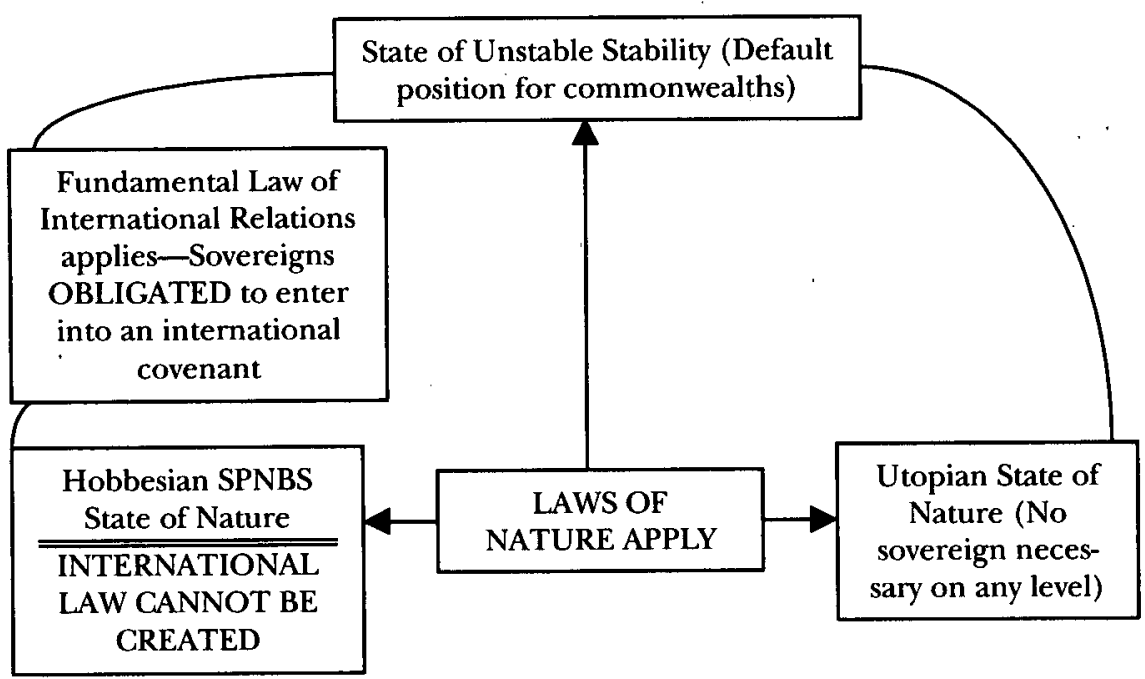

D. That the Sovereign Cannot Be Subject to the Civil Laws

I have been arguing that the municipal sovereign is the author of any newly created international sovereign's acts, so that the acts of the newly created international sovereign are also the acts of the original municipal sovereign. However, Hobbes states:

A fourth opinion repugnant to the nature of a commonwealth is this: That he that hath the sovereign power is subject to the civil laws. It is true that 
sovereigns are all subject to the laws of nature . . . But to those laws which the sovereign himself, that is, which the commonwealth maketh, he is not subject. For to be subject to laws is to be subject to the commonwealth, that is, to the sovereign representative, that is, to himself, which is not subjection, but freedom from the laws. Which error, because it setteth the laws above the sovereign, setteth also a judge above him, and a power to punish him, which is to make a new sovereign; and again for the same reason a third, to punish the second; and so continually without end, to the confusion and dissolution of the commonwealth. ${ }^{155}$

By allowing the sovereign to give up some of its sovereignty, are we not allowing it to create more and more sovereigns without end? And if so, does this not tend toward confusion, as Hobbes said? ${ }^{156}$

To answer this challenge, I return to our hypothetical pre-Union Europe. Belgium has just covenanted with the Netherlands and Luxembourg to enter into a limited European Union, which will have the power only to deal with pollution. Belgium has passed a statute allowing a pollution level of $0.005 \mathrm{ppm}$ in the air. The European Union has issued a directive ${ }^{157}$ to the Member States not to allow a pollution level of greater than $0.002 \mathrm{ppm}$. This, however, is not the confusioncausing situation of which Hobbes speaks.

Hobbes's theory objects to subjecting the sovereign of commonwealth $X$ to the civil laws of commonwealth $X$, not with subjecting the sovereign of commonwealth $X$ to the civil laws of newly created commonwealth $X Y Z$. Looking at this European Union, Belgium has undertaken an obligation to obey the international sovereign and, as such, must obey the Union's rules regarding pollution. It is clear that the European Union directive supersedes the law of Belgium. There is no confusion. The confusion Hobbes speaks of would exist only if Belgium were to be judged by one of its own subjects as to whether it is complying with its own laws. Here, Belgium's compliance with the

${ }^{155}$ HOBBES, supra note 50 , at ch. xxix, para. 9.

156 There must be an answer to this objection for Hobbes's theory of municipal sovereignty to work. For in the state of nature, each individual can be defined as its own unique mini-sovereign entity. By entering into the initial covenant and authoring the acts of a municipal sovereign, each individual "mini-sovereign" would be subjecting itself to its own civil laws. It would seem as if Hobbes would deny the value of his own theory by accepting this interpretation of his text.

${ }^{157}$ A directive within the European Union legal structure is a piece of legislation passed by the European Union that is binding as to the result to be achieved, but leaves to the national authorities the choice of how to implement legislation to achieve the results. See EC TREATY, supra note 37, at art. 249 (describing the various forms of legislating within the European Union); see also BERMANN ET AL., EUROPEAN COMMUNITY LAW, supra note 4, at 75 (differentiating directives from regulations). 
European Union laws is judged by one of the European Union's subjects, who also may be a subject of Belgium, but in a different role.

In response, one may throw my argument back at me. Have I not just stated that the international sovereign's actions are the actions of the municipal sovereigns? I answer that civil international law is not the type of law that Hobbes was alluding to in his passage. Rather, Hobbes was alluding strictly to subjecting the civil sovereign to civil municipal law. Let us take a hypothetical household in Belgium, the Cooke household. Mrs. Cooke is known as the rulemaker in her household. She decides when to have dinner, what can be viewed on the television, etc. Hobbes argued that she should not be held to her own rules. For if Mrs. Cooke were subject to her own laws, who would judge her? If her rule was that no one was to eat spaghetti that she considered too al dente in her household, only she could be the judge of that. However, Mrs. Cooke should be subject to the municipal sovereign's rules, even though they are partly her own. Being subject to the sovereign's laws, while they are authored by her as well, provides an efficient system by which her actions may be judged.

Returning to the European Union, if Belgium had a law stating that pollution levels could not rise above that level which the Belgian sovereign deemed reasonable, then only the Belgian sovereign could be the judge of reasonableness. However, if an international law supersedes the Belgian law, Belgium is no longer required to be the judge of reasonableness, and now has a separate, efficient system by which reasonableness of pollution will be judged.

\section{E. Limiting the Power of the Sovereign to Enter into an Intermational Legal Structure}

Earlier in this Comment, I spoke of the subjects' ability to limit the power they give to their own sovereign. ${ }^{158}$ This must allow for the possibility that the subjects may limit the sovereign's power to enter into an international agreement.

For subjects to limit the ability of a sovereign to enter into a treaty that limits sovereignty, the subjects' covenants with each other must consist of some variation of "I, Jon, agree that I will take upon a duty toward you, Gary, that I will obey Germany, which shall have unlimited power over me and unlimited privileges, with the exception that it not have the power to cede any of its sovereignty. If it does attempt

${ }^{158}$ Supra notes 90-93 and accompanying text. 
to cede its sovereignty, my duty toward you is dissolved, as is the commonwealth itself." Another variation may call for Germany to have a referendum if it wants to cede sovereignty. It would read, "I, Jon, agree that I will take upon a duty toward you, Gary, that I will obey Germany, who shall have unlimited power over me and unlimited privileges. However, I do not agree to give it the power to cede any of its sovereignty without consulting all of its subjects in the form of a referendum. If it attempts to do so, my duty to obey is dissolved." This does not subject Germany to civil municipal law, ${ }^{159}$ and Germany is free to organize the referendum in any way it pleases. It does, however, limit Germany's ability to cede its sovereignty.

These types of covenants exist today. For example, article 54 of the constitution of the French Republic reads:

If the Constitutional Council, when consulted by the President of the Republic, the Prime Minister, or the president of one of the houses of Parliament, declares that an international treaty or agreement contains a clause contrary to the Constitution, the Constitution must be revised before the treaty or agreement can be ratified or approved. ${ }^{160}$

Thus, if the Constitutional Council ruled that an international treaty in which France ceded a portion of its sovereign rights to another sovereign violated the French constitution, the constitution would have to be revised before the treaty could be approved. However, article 92 of the Dutch constitution permits the transfer by treaty of legislative, executive, and judicial powers to international institutions. $^{161}$ Similarly, article 24 of the Basic Law of the Federal Republic of Germany explicitly states: "The Federation may by legislation transfer sovereign powers to inter-governmental institutions." ${ }^{162}$ While the U.S. Constitution does not speak directly to the cessation of sovereignty, it does set out a procedure by which the sovereign may create international treaties. ${ }^{163}$

Whether or not parties to a Hobbesian contract will think in advance to limit the sovereign's power with respect to international agreements is an uncertain question. It would seem that to Hobbes,

${ }^{159}$ See supra Part III.D (discussing the problems of subjecting a sovereign to its own civil municipal law).

${ }^{160}$ Fr. CONST. (Constitution of the French Republic) art. 54.

161 NETH. CONST. (Dutch Constitution of the Netherlands) art. 92.

${ }_{163}^{162}$ F.R.G. CONST. (Basic Law of the Federal Republic of Germany) art. 24, § 1.

163 "[The President] shall have Power, by and with the Advice and Consent of the Senate, to make Treaties, provided two thirds of the Senators present concur ....." U.S. Const, art. 2, § 2, cl. 2. 
whose time was one of "civil strife and war," the only goal at the time of the original covenant was an absolute sovereign. Indeed, Hobbes seems to have a preference for absolute sovereignty:

So that is appeareth plainly . . that the sovereign power (whether placed in one man, as in monarchy, or in one assembly of men, as in popular and aristocratical commonwealths) is as great as possibly men can be imagined to make it. And though of so unlimited a power men may fancy many evil consequences, yet the consequences of the want of it, which is perpetual war of every man against his neighbour, are much worse. ${ }^{165}$

It does seem that after a period of such war, humans would want the strongest sovereign imaginable. It is possible, however, to conceive of a different situation in which entities may create a new civil society after a long period of despair under a despot, and thus would be suspicious of another absolute sovereign. ${ }^{166}$ Hobbes seems to be speaking merely from his own experience in making the above statement. One can imagine many reasons why entities would limit the power of their sovereign.

Whether or not the entities creating a sovereign are inclined to create limitations on the sovereign authority, a third corollary to the Fundamental Law of International Relations is required. That is, before one may accept the ceding of sovereignty as instantly valid, one must examine the original covenant that created the commonwealth to see whether the sovereign was given the power to cede its authority. Thus, the final version of the Fundamental Law of International Relations reads:

When a municipal sovereign sees that its commonwealth is tending toward the Hobbesian SPNBS state of nature from the state of unstable stability with respect to other states, so long as the municipal sovereign deems necessary, so long as the sovereign has the power to do so, and so long as other sovereigns are willing to do so, it must lay down its own sovereignty to create an international sovereign whose powers will not exceed the powers granted the municipal sovereign by its subjects.

Thus, auto-limitation remains, but not in an implicit form. It must be expressed in the original covenant.

164 PLAMENATZ, supra note 15 , at 116.

${ }^{105}$ HOBBES, supra note 50, at ch. $\mathrm{xx}$, para. 18; see also supra note 74 (commenting on Hobbes's preference for an absolute sovereign).

${ }^{160}$ For a discussion of how humans deliberate and might come to the conclusion that an absolute sovereign is less secure than a limited one, see HOBBES, supra note 50 , at chs. i-vii. 


\section{CONCLUSION}

I have shown that, at times, the laws of nature oblige a municipal sovereign to cede its sovereignty and formulate an international sovereign. Accordingly, one advocating the auto-limitation theory must reconcile that belief with the fact that he is arguing against the laws of nature. Thus, sovereigns may take upon themselves legal obligations.

Returning to Society for the Protection of Unborm Children (Ireland) Ltd. v. Grogan, ${ }^{167}$ assume that the Council of the European Union has issued a directive requiring Member States, even those who outlaw abortion, to allow the distribution of pamphlets indicating where their residents could go to receive a legal abortion. Further assume that the time for implementation of this directive has passed, and the directive now applies to members of each state through the "direct effects" doctrine.$^{168}$ Further assume that this directive is compatible with the jurisprudence of the European Court of Justice and is in accord with the European Convention on Human Rights. Finally, assume that Ireland maintains its injunction against the students.

Since Ireland's powers were not limited expressly in its constitution, and the European Union does not have any more powers than were initially granted the Irish government, the directive must prevail. Ireland was permitted to enter into the agreement creating the European Union, which is an international legal structure. It has a duty toward the other Member States to obey the law of the new legal structure.

It is as important to note what I am not claiming here as much as what I am claiming. I am not claiming that all treaty obligations are initially valid. I am merely claiming that some may be so. The framework in which the issue of the validity of international law must be addressed is whether countries adhering to this law in fact ceded their authority. A treaty that does not set up an international legal sovereign is what proponents of the auto-limitation theory think all treaties are: statements of future intentions. However, once it has been determined that the treaty not only stated intended future acts, but actually ceded some authority (as in the European Union), the laws

${ }^{167}$ [1990] 1 C.M.L.R. 689 (Ir. S.C. 1989).

${ }^{168}$ A directive is binding only as to the Member States and not their residents. See supra note 157 (describing the legal effect of a directive). However, once the time limit given to implement the directive has expired, the directive may be said to be "directly applicable" to the citizens of each Member State. Case 41/74, van Duyn v. Home Office, 1974 E.C.R. 1337, 1346, [1975] 1 C.M.L.R. 1 (1974). 
passed by the new international sovereign are valid international law. Laws created by a properly instituted international sovereign are properly called laws. The hypothetical cases discussed in Internationale Handelsgesellschaft and Society for the Protection of Unborn Children have already been decided. The European Union law prevails and the Member States have a duty to obey. 
* * * * * * * * 